THE NEW SOVEREIGNTY 



\title{
The New \\ Sovereignty
}

Compliance with International

Regulatory Agreements

\author{
ABRAM CHAYES \\ ANTONIA HANDLER CHAYES
}

Harvard University Press

Cambridge, Massachusetts

London, England

1995 
Copyright () 1995 by Abram Chayes and Antonia Handler Chayes All rights reserved

Printed in the United States of America

Library of Congress Cataloging-in-Publication Data

Chayes, Abram, 1922-

The new sovereignty : compliance with international regulatory agreements / Abram Chayes, Antonia Handler Chayes.

p. $\mathrm{cm}$.

Includes bibliographical references and index.

ISBN 0-674-61782-7 (cloth : alk. paper)

1. Treaties. 2. Compliance. 3. Sovereignty.

I. Chayes, Antonia Handler, 1929- ～～II. Title.

JX4165.C43 1995

$341.3^{\prime} 7$ - dc20

95-21960 
To each other 
